Portland State University

PDXScholar

Institute for Sustainable Solutions Publications

and Presentations

Institute for Sustainable Solutions

7-1-2006

\title{
Toward an ecological economy
}

Robert Costanza

Portland State University

Follow this and additional works at: https://pdxscholar.library.pdx.edu/iss_pub

Part of the Sustainability Commons

Let us know how access to this document benefits you.

\section{Citation Details}

Costanza, R. (2006). TOWARD AN ECOLOGICAL ECONOMY. Futurist, 40(4), 26.

This Article is brought to you for free and open access. It has been accepted for inclusion in Institute for Sustainable Solutions Publications and Presentations by an authorized administrator of PDXScholar. Please contact us if we can make this document more accessible: pdxscholar@pdx.edu. 


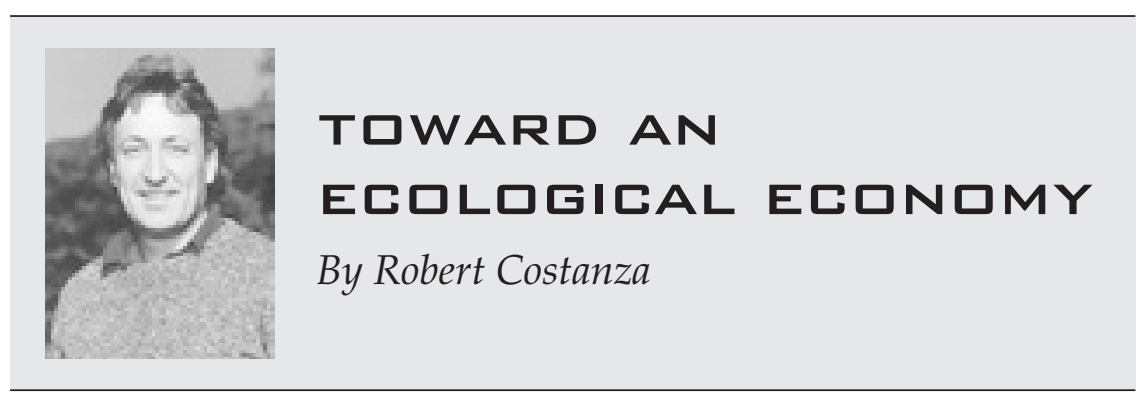

L ester Brown does an excellent job of describing what an ecological economy might look like, at least in its technical dimensions. He also points out that "if economic progress is to be sustained, we need to replace the fossil-fuelbased, automobile-centered, throwaway economy with a new economic model."

To do this, we need to create a new vision of what the economy is, what it is for, and how to measure success. What is "economic progress," after all? The "economy" we usually hear about refers only to the market economy-the value of those goods and services that are exchanged for money. Its purpose is usually taken to be to maximize the value of these goods and services-with the assumption that the more economic activity there is, the better off we are. Thus, the more GDP (which measures aggregate activity in the market economy), the better. But the purpose of the economy should be to provide for the sustainable wellbeing of people. That goal encompasses material well-being, certainly, but also anything else that affects well-being and its sustainability.

There is substantial new psychological research in the emerging "science of happiness" that shows the limits of conventional economic income and consumption in contributing to well-being. If we want to assess the "real" economy-all the things that contribute to real, sustainable, human welfare-as opposed to only the "market" economy, we have to measure the non-marketed contributions to human well-being from nature; from family, friends, and other social relationships at many scales; and from health and education.

One convenient way to summarize these contributions is to group them into four basic types of capital that are necessary to support the real, human-welfare-producing economy: built capital, human capital, social capital, and natural capital. Brown acknowledges the importance of natural capital in supporting human welfare, and here I'd like to flesh out some of the implications of this for redefining economic progress.

In the future ecological economy, we will not be able to sustain an ever-increasing gross domestic product, and we will not want to. GDP is limited, measuring only marketed economic activity or gross income. It also counts all of this activity as positive. It does not separate desirable, well-being-enhancing activity from undesirable, well-being-reducing acto clean it up, but it obviously detracts from society's well-being. From the perspective of GDP, more crime, more sickness, more war, more pollution, more fires, storms, and pestilence are all potentially good things, because they can increase marketed activity in the economy.

GDP also leaves out many things that enhance well-being but are outside the market. For example, the unpaid work of parents caring for their own children at home doesn't show up, nor does the non-marketed work of natural capital in providing clean air and water, food, climate regulation, and a host of other ecosystem services, estimated in aggregate to be worth significantly more than GDP. Finally, GDP takes no account of the distribution of income among individuals. But it is well known that an additional $\$ 1$ worth of income produces more well-being if one is poor rather than tivity. For example, an oil spill increases GDP because someone has rich. It is also clear that a highly skewed income distribution has negative effects on a society's social capital.

We need much better ways of measuring real well-being. One attempt, the Genuine Progress Indicator (GPI), addresses these problems by separating the positive from the negative components of marketed economic activity. It also adds in estimates of the value of non-marketed goods and services provided by natural, human, and social capital, and it adjusts for income-distribution effects. While it is by no means a perfect representation of the real wellbeing of the nation, GPI is a much better approximation than GDP. While GDP has steadily increased in the United States since 1950, with the occasional dip or recession, GPI peaked in about 1975 and has been gradually decreasing ever since. From the perspective of the real economy, as opposed to just the market economy, the United States has been in recession since 1975 .

An ecological economy would thus have to redefine "economic progress" to mean not merely "growth in GDP," but rather improvement in real, sustainable human welfare-something more akin to GPI. In fact, GDP may have to go down so that GPI can go up. This is not a sacrifice. Quite the contrary. It would be a real improvement in our sustainable quality of life (as opposed to a misleading measure of gross activity). It would help us to create a compelling and positive shared vision of a significantly better future. Without creating such a vision, we stand little chance of achieving it.

\section{About the Author}

Robert Costanza is the Gordon Gund Professor of Ecological Economics and director of the Gund Institute of Ecological Economics at the Rubenstein School of Environment and Natural Resources, The University of Vermont-Burlington, Burlington, Vermont 05405. Web site www.uvm.edu.

FEEDBACK: Send your comments about this article to letters@wfs.org. 
Copyright of Futurist is the property of World Future Society and its content may not be copied or emailed to multiple sites or posted to a listserv without the copyright holder's express written permission. However, users may print, download, or email articles for individual use. 